\title{
Comprehensive assessment of the Aral Sea region children's health conditions
}

\author{
Gulnara Tashenova ${ }^{1, *}$, Raushan Issayeva ${ }^{1}$, Aigerim Aliakparova $^{1}$, Riza Boranbayeva ${ }^{2}$, \\ Lyazzat Sarsenova ${ }^{1}$ \\ ${ }^{1}$ Al-Farabi Kazakh National University, al-Farabi Ave. 71, 050040 Almaty, Kazakhstan \\ ${ }^{2}$ Scientific Center of pediatrics and child Surgery, al-Farabi Ave. 146, 050060 Almaty, Kazakhstan
}

\begin{abstract}
A comprehensive assessment of the health status of 757 children in the Aral Sea region was performed, by assesing the direction of their pathology based on the results of medical, clinical, laboratory, instrumental and socio-psychological studies. The distribution by health groups showed a predominance of functional abnormalities among children (group II (50.0\%), group III (28.7\%), and chronic diseases at the age of 11-15 years. Healthy children accounted for only $9.2 \%$. According to the structure of morbidity, vegeto-vascular dystonia dominated in $55.2 \%, 52.2 \%$ showed functional disorders of the digestive system and iron-deficient anemia (19.7\%). The revealed psychological features manifested by a high level of anxiety in children of the Aktobe region (57,0\%). Studies have indicated low children's health in environmentally depressed areas, which may be one of the significant factors contributing to the formation of various forms of chronic pathology.
\end{abstract}

\section{Introduction}

Current negative trends in the state of the environment have acquired a particularly significant problem for residents of the Aral Sea region, who affected by a set of specific risk factors due to the consequences of environmental degradation in connection with the ecological tragedy of the Aral Sea [1]. Today, the Aral Sea and its surrounding territories have become famous worldwide due to an anthropogenic environmental disaster. The main reason for the difficult environmental situation in the Aral Sea region was the large-scale anthropogenic interference. Protecting public health and taking care of the quality of the environment is one of the relevant areas of environmental safety of any state [2].

Genome instability was detected, defined as the whole complex of changes characterizing the transformation of a normal cell into a tumor, which was more pronounced in children in Aralsk. Significant positive correlations $(\mathrm{p} \leq 0.05)$ were found between the level of children's anxiety and the rate of blood cell division in culture, which is associated with the processes of early aging. The data obtained allow the authors to conclude that the high incidence of children living in the Aral Sea basin as well as increased genome instability and its individual sensitivity is the most likely consequence of poverty and malnutrition, etc., that is, they are the result of (indirect) influence of socio-economic problems [3, 4].

\footnotetext{
* Corresponding author: aknur.zh@gmail.com
} 
According to some reports, changes in the cardiovascular system in children in areas of ecological distress are more often characterized by the development of vegetative-vascular dystonia and myocardial dystrophy [5, 6].

According to official statistics of the Ministry of Health and Social Development of the Republic of Kazakhstan, the prevalence of IDA in children from 0 to 14 years in 2018 amounted to 4351.5 per 1000 population. The highest prevalence rates of anemia occur in children under the age of 3 years - 69\% [7]. Most studies have shown an association between IDA in children under one year of age and late cognitive development. Moreover, it was found that iron deficiency even without anemia can adversely affect the child's neurodevelopment and behavior, and that some of these consequences may be irreversible [8].

Comparative studies of the incidence of children under 3 years of age have shown that the leading places in both Almaty and Kyzylorda regions are occupied by respiratory diseases, anemia and digestive diseases, and, moreover, the prevalence of these diseases was much higher in the Kyzylorda region [9] .

The abilities of various xenobiotics (insecticides, biphenyls, methylcholanthrene) have been established to significantly reduce the content of vitamin A in the liver and thereby disrupt the body's supply with this vitamin. It is obvious that a similar situation can occur in potentiated expression in cases of combined exposure to xenobiotics in ecologically crisis regions, infectious and other diseases, in particular, liver, kidney diseases and associated with a high risk to the health of the population, especially children. [10].

Today, the problem of maintaining and improving children's health is given special importance in connection with unfavorable trends - the progressive increase in chronic forms of somatic pathology and neuropsychic diseases, the number of socially maladaptive children and disabled people in the country [11].

The results of numerous epidemiological studies indicate that most children suffer from three to five episodes of ARI during the year, and the incidence is 2-2.5 times higher in children of the first three years of life than at the age of 10 years and older. Recurrent respiratory infections lead to a violation of the functional state of the body, can cause a failure of adaptation and cause the development of chronic pathology [12].

The highest level of newly diagnosed pathology was noted in the following classes of diseases: blood and blood-forming organs diseases - 32\%, primarily due to anemia (33.0\%), digestive organs diseases $-24.7 \%$ and circulatory system diseases $-24 \%$ [13].

An analysis of the current situation shows that the causes of this catastrophic situation are socio-economic instability in society, the poor sanitary state of the environment for children (learning conditions and conditions, living conditions, etc.), the environmental situation, the reform of the education and healthcare systems, and low medical activity and health literacy of the population, curtailing preventive work, etc.

Therefore, one of the urgent problems of hygiene of children and adolescents is the study of the influence of environmental factors on the state of health and development of children and adolescents. There is a direct relationship between the level of anxiety in children and the state of the blood lymphocyte genome. This relationship demonstrates that one of the main sources of increased instability of the children's genome in the Aral Sea region is a nonadaptive level of anxiety directly related to the socio-economic conditions of the region. [4].

\section{Materials and methods}

In accordance with the purpose and objectives of the study, 750 children aged 5-17 years living in the Aral Sea region were examined (Irgiz village - 250 children: boys - $122-48.8 \%$, girls - 128 - 51.2\%; Shalkar - 250: boys - 129-51.6\%, girls - 121-48.4\%; Arys -250: boys $124-49.6 \%$, girls $126-50.4 \%$ and 750 children from the Karaganda region (Ulytau village 
250: boys - $127-50.8 \%$, girls - $123-49.2 \%$; the village of Atasu - 500: boys - $256-51.2 \%$, girls - $244-48.8 \%$ ).

The following research methods were performed:

1. Clinical examination of 1,500 children living in the village. Irgiz, Shalkar and the city of Arys, pos. Ulytau and Atasu.

2. Anthropometric and psychophysiological studies, variational pulsometry, blood pressure determination, cognitive brain functions, psychological tests to determine the degree of psychological maturity and tension, aggressiveness, anxiety.

3. Clinical, functional and instrumental methods: objective examination of specialists by fluorography, electrocardiography (ECG), cardiointervalografia (CIG), ultrasound examination of the kidneys and abdominal organs, peak flowmetry.

4. General clinical studies of blood and urine, 3532 studies on various biochemical parameters (ALT, AST, total bilirubin, cholesterol, chlorides, creatinine, CRP, Fe, ferritin, glucose, total protein, transferrin, urea, Mg, P, Ig A, Ig M, Ig G, Ig E).

5. A comprehensive medical and social examination of the families of 757 children aged 5 to 17 years was carried out in the village. Irgiz, Shalkar and the city of Arys. The study consisted of a sociological survey of mothers or guardians using a specially designed questionnaire to clarify the medical and social factors that determine the standard of living of the children studied.

\section{Results and discussion}

The analysis of children's health groups in Aktobe, Karaganda and Kyzylorda regions showed that in the examined children, the second group is health group (50.0\%), then the third group $(28.7 \%)$.

We found that in all settlements in most cases the II group of health was met from $50 \%$ to $83.2 \%$. The I group of health of children in whom somatic disorders (healthy) and children with minimal disorders in the form of dental caries and skin lesions in the form of simple lichen, acute respiratory viral infections, are most often noted in Irgiz (22\%) and in Ulytau $(21,9 \%)$, while the III group of children with various pathologies of organs and systems of moderate severity in most cases was found in the city of Arys (28.7\%). The percentage of severe, due to health reasons, groups of children (IV and V gr) were more common in the Kyzylorda region in the city of Arys. So, in the city of Arys SKO with. Ulytau, indicators of the frequency of these groups of children ranged from $5.2 \%$ to $0.7 \%$. In the village of Irgiz, children from group IV - V were not identified. In the Karaganda region of Atasu village, group IV was not identified, and group V was found only in $0.1 \%$ of cases (Figure 1).

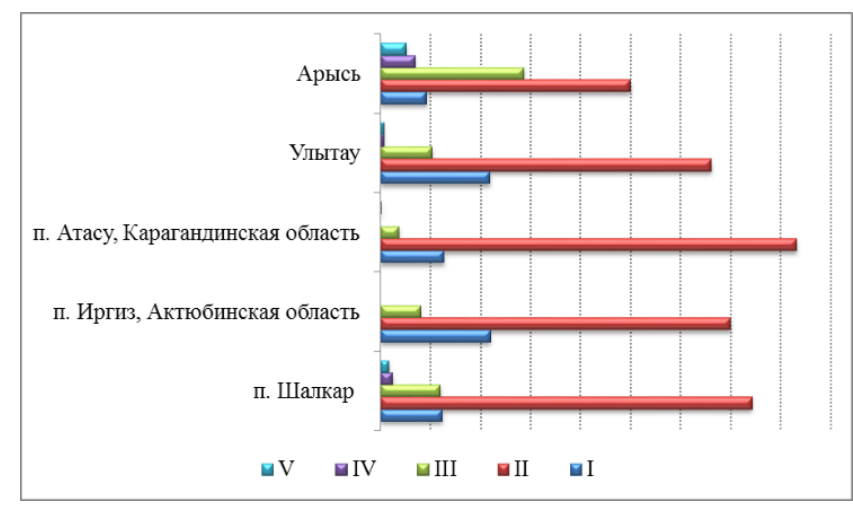

Fig. 1. Comparative characteristics by health groups in the studied regions. 
Thus, the most favorable for health reasons are the regions of Ulytau (21.9\%) and Irgiz (22\%), where children of group I made up a larger percentage.

In the structure of functional abnormalities in children in the Aral Sea region, in 55.2\% (276) cases, vegetative dysfunction occurred, which was more often detected in children of preand puberty age (78.9\%) and mainly in girls $(80.8 \%)$.

According to various literature data, certain signs of vegetative-vascular dystonia are diagnosed in $25-82 \%$ of children. Vegetative disorders in children can give impetus to the development of serious pathological conditions - arterial hypertension, bronchial asthma, gastric ulcer, etc. Vegetative dysfunctions have a multifactorial developmental genesis, and predisposing factors may include foci of chronic infections such as chronic tonsillitis, caries, pharyngitis, sinusitis [14]. The direct triggers of autonomic dysfunction in most cases are adverse weather conditions, climatic features, an unfavorable environmental situation, an imbalance of trace elements, poor nutrition, hormonal restructuring of the pubertal period, etc. [15]. All these factors are characteristic of the Aral Sea region and could be the reason for the formation of autonomic dysfunction in children living in this region.

The frequency of autonomic dysfunction in children in a comparative aspect by place of residence, by age and gender is presented in Table1.

Table 1. The frequency of autonomic dysfunction in children depending on the place of residence, age and gender (percentage)

\begin{tabular}{|c|c|c|c|c|c|c|c|c|c|c|c|}
\hline \multirow{3}{*}{$\begin{array}{l}\text { Place of } \\
\text { residence/ } \\
\text { Age/Gender }\end{array}$} & \multicolumn{11}{|c|}{ Vegetative dysfunction } \\
\hline & \multicolumn{2}{|c|}{ 5-7 years } & \multicolumn{2}{|c|}{$8-10$ years } & \multicolumn{2}{|c|}{$11-13$ years } & \multicolumn{2}{|c|}{$14-17$ years } & \multicolumn{2}{|c|}{ 5-17 years } & \multirow[t]{2}{*}{ Total } \\
\hline & $\mathrm{M}$ & Д & $\mathrm{M}$ & Д & $\mathrm{M}$ & Д & $\mathrm{M}$ & Д & $\mathrm{M}$ & Д & \\
\hline Irgiz & 38,5 & 57,9 & 40,0 & 44,8 & 56,0 & 96,4 & 17,1 & 55,8 & 35,2 & 62,5 & $123-49,2$ \\
\hline Shalkar & 19,0 & 45,8 & 41,9 & 51,8 & 46,1 & 67,6 & 28,9 & 92,8 & 31,4 & 65,5 & $117-46,8$ \\
\hline Arys' & 21,9 & 30,0 & 11,9 & 41,4 & 44,8 & 75,0 & 21,0 & 90,0 & 27,1 & 59,5 & $107-42,8$ \\
\hline Ulytau & 12,9 & 21,4 & 28,6 & 36,4 & 16,1 & 59,4 & 10,8 & 50,0 & 16,5 & 42,3 & $73-29,2$ \\
\hline Atasu & 9,5 & 10,9 & 19,7 & 31,7 & 20,3 & 40,3 & 15,9 & 52,7 & 16,4 & 33,2 & $123-24,6$ \\
\hline
\end{tabular}

As can be seen from table 1, in children in the Aral Sea region (the villages of Shalkar, Irgiz, Arys) vegetative dysfunction was observed almost twice as often (> 46.3\%) than in children living in the Karaganda region (Ulytau - 29.2\% and Atasu - 24.6\%). An analysis of the options for the imbalance of autonomic regulation in children in the studied regions showed that in the overwhelming majority of cases a vagotonic type is observed - more than $75.5 \%$, a mixed type is second in frequency - $17.3 \%$ and a sympathetic -otonic type of autonomic dysfunction is third $-7,2 \%$.

According to our studies, in children with autonomic dysfunction, the most frequent complaints of a neurological nature were headaches (100\%), fatigue (30.0\%), sleep disturbance $(17.0 \%)$, poor memory $(27.0 \%)$, dizziness $(37.0)$, and vestibular disorders $(31.0 \%)$. Children with SVD had a lowered mood and anxiety $(60.4 \%)$.

On the part of the cardiovascular system, autonomic dysfunction in children was manifested in the form of complaints of pain in the region of the heart (100\%), palpitations at the slightest exertion (17.0\%). Arterial hypotension was detected in $39.4 \%$ and arterial hypertension in $0.4 \%$ of cases in children of the studied region.

Functional cardiopathies in children, due to autonomic dysfunction, manifested mainly in the form of arrhythmias. According to the ECG, sinus bradyarrhythmia prevailed in the structure of heart rhythm disturbances - 24.6-2.7\%; sinus arrhythmia - 22.0-2.6\% and sinus tachycardia $-8.0-1.7 \%$. Migration of the pacemaker was $0.6-0.4 \%$, supraventricular extrasystole - 1.3-0.8\%. Among conduction disturbances, an incomplete blockade of the right bundle branch block was revealed - 43.3-3.1\%. Elongation of the atrioventricular conduction was detected in $1.3-0.7 \%$, shortening of the PQ interval and alternation of the ventricular 
complex by $0.6 \%$, respectively. Metabolic disorders in the ventricular myocardium were detected in $27.0-2.8 \%$ of children.

According to Isaeva R.B. analysis of the distribution of various forms of somatic pathology by systems showed that in 2004-2007, the examined children of the Aral Sea region most often revealed chronic diseases of the digestive system (98-100\%) [16].

Among the diseases of the gastrointestinal tract detected in children of the Aral Sea region by us, functional disorders were the leading form of pathology. Damage to the hepatobiliary system $(62.0 \%)$ and functional dyspepsia $(52.2 \%)$ dominated in the structure of the pathology of the digestive tract. The frequency of pancreatic pathology was greatest among children in the city of Arys - 49.9\%, among children in the Irgiz and Shalkarsky districts, it was observed on average in $44.2 \%$, and among children in the villages of Atasu and Ulytau of the Karaganda region on average $30 \%$ of cases. children are presented in Table 2.

Table 2. Characterization of complaints in children with gastroduodenal pathology.

\begin{tabular}{|c|c|c|c|c|c|c|}
\hline \multirow[b]{2}{*}{ Complains } & \multicolumn{5}{|c|}{ Place of residency of the children examined } & \multirow[b]{2}{*}{ average, $\%$} \\
\hline & $\begin{array}{c}\text { Irgiz, } \% \\
\mathrm{n}=250\end{array}$ & $\begin{array}{c}\text { Shalkar,\% } \\
\mathrm{n}=250\end{array}$ & $\begin{array}{c}\text { Arys',\% } \\
n=250\end{array}$ & $\begin{array}{c}\text { Ulytau, \% } \\
\text { n=500 }\end{array}$ & $\begin{array}{c}\text { Atasu, \% } \\
\mathrm{n}=250\end{array}$ & \\
\hline nausea & 25,6 & 27,0 & 32,8 & 18,8 & 23,4 & 25,5 \\
\hline burping & 11,2 & 12,8 & 16,9 & 14,1 & 9,6 & 12,9 \\
\hline heartburn & 15,4 & 14,0 & 24,8 & 21,9 & 13,2 & 17,8 \\
\hline $\begin{array}{l}\text { decreased } \\
\text { appetite }\end{array}$ & 18,6 & 15,4 & 17,8 & 22,7 & 15,1 & 17,9 \\
\hline stomach ache & 45,2 & 44,8 & 43,2 & 57,9 & 41,2 & 46,4 \\
\hline constipation & 45,6 & 43,0 & 38,4 & 63,0 & 42,3 & 46,4 \\
\hline $\begin{array}{l}\text { stomach pain }+ \\
\text { constipation }\end{array}$ & 47,0 & 43,4 & 39,7 & 46,4 & 35,8 & 42,5 \\
\hline unstable chair & 12,7 & 8,4 & 8,0 & 15,3 & 9,5 & 10,7 \\
\hline flatulence & 15,8 & 19,4 & 16,5 & 23,4 & 11,4 & 86,5 \\
\hline
\end{tabular}

The results of an ultrasound examination of the abdominal organs confirmed the data of clinical observations, indicating a significant prevalence of pathology of the gastrointestinal tract in the examined population (Table 3 ).

Table 3. The structure of gastrointestinal diseases in children.

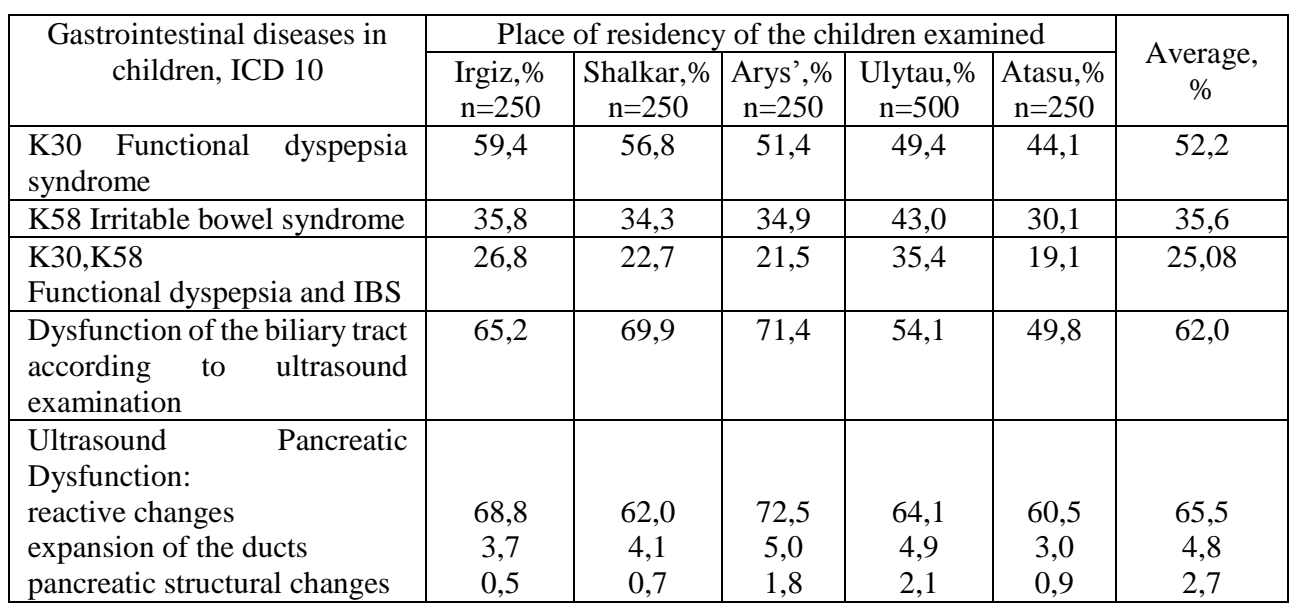

Of the examined, in most cases anemia was detected in children living in the Irgiz 
settlement - $19.6 \%$, then in descending order - in $9.3 \%$ of the children of Arys, 42 children (8.4\%) of the Zhanaarkinsky district Atasu and in 13 children (5.2\%) c. Ulytau, $4.8 \%$ of children living in Shalkar. The frequency of IDA prevails in adolescents, so the largest number of children in this age group is detected in Shalkar - 58.3\% (Table 4).

Table 4. Anemia frequency according to age.

\begin{tabular}{|c|c|c|c|c|c|}
\hline $\mathrm{Age} \mathrm{n}$ & $\begin{array}{l}\text { Arys' } \\
24\end{array}$ & $\begin{array}{c}\text { Irgiz } \\
49\end{array}$ & $\begin{array}{c}\text { Shalkar } \\
12\end{array}$ & $\begin{array}{c}\text { Atasu } \\
42\end{array}$ & $\begin{array}{c}\text { Ulytau } \\
15\end{array}$ \\
\hline $5-7$ & 38.5 & 28.6 & 25 & $21,4 \%$ & $13,3 \%$ \\
\hline $8-11$ & 20.83 & 18.36 & 0 & $11,9 \%$ & $26,6 \%$ \\
\hline $12-14$ & 0 & 26.5 & 16.6 & $26,2 \%$ & $20 \%$ \\
\hline $15-17$ & 41.6 & 26.5 & 58.3 & $40,5 \%$ & $40 \%$ \\
\hline
\end{tabular}

In terms of severity, anemia of the first degree prevailed in $91.8 \%$ and $87.5 \%$ in the towns of Irgiz and Arys, the smallest number of identified children with anemia of the first degree in s. Atasu. Grade II anemia was detected in $26.6 \%$ of children with. Ulytau and in $25 \%$ of children in the village of Shalkar. In the settlement of Irgiz, $8.16 \%$ of children showed anemia of the II degree of severity (table 24). In the city of Atasu, among 5 children, deep grade III anemia was detected with a hemoglobin level of $70 \mathrm{~g} / 1 ; 51 \mathrm{~g} / 1$

According to WHO, IDA is found in all countries of the world, however, its prevalence is not the same, which depends on numerous reasons - socio-economic conditions, population income, diet, etc. The main cause of iron deficiency in the human body, according to WHO experts, this is an improper (defective) diet [8].

Respiratory diseases in the structure of childhood diseases still maintain a leading position, while bronchopulmonary diseases accompanying the development of bronchial obstruction syndrome (SBO) are coming to the fore [17]. Among these diseases, the leading place belongs to bronchial asthma (AD), which attract the attention of pediatricians in connection with their prevalence, the difficulty of differential diagnosis and the choice of optimal therapy [18].

In order to increase the efficiency of detecting a disease in recent years, the international ISAAC program has been widely used, which allows one to determine AD by the main symptoms of the disease (wheezing in the anamnesis of the last 12 months, attacks of nocturnal suffocation, wheezing during physical exertion, isolated night cough), and not according to established diagnoses. A survey was conducted of 1,500 children (Table 5). Prior to the study in the village. Shalkar and Irgiz revealed only 7 children with a diagnosis of asthma and 18 children in the village of Arys, p. Ulytau, 8 children and p. Atasu 3 children. None of the patients received adequate basic therapy.

Table 5. Frequency (\%) of the asthma-like symptoms among the examined children.

\begin{tabular}{|c|c|c|c|c|c|c|c|c|}
\hline \multirow[t]{2}{*}{ Symptoms } & \multicolumn{2}{|c|}{$\begin{array}{c}\text { Shalkar and } \\
\text { Irgiz } \\
\text { (500 kids) }\end{array}$} & \multicolumn{2}{|c|}{$\begin{array}{c}\text { Arys' } \\
(250 \text { kids })\end{array}$} & \multicolumn{2}{|c|}{$\begin{array}{c}\text { Ulytau } \\
\text { (250 kids) }\end{array}$} & \multicolumn{2}{|c|}{$\begin{array}{c}\text { Atasu } \\
\text { (500 kids) }\end{array}$} \\
\hline & \# & $\%$ & \# & $\%$ & \# & $\%$ & \# & $\%$ \\
\hline a history of wheezing & 120 & 24.4 & 74 & 29.6 & 31 & 12.4 & 11 & 2.2 \\
\hline wheezing in the last 12 months & 110 & 22.0 & 63 & 25.2 & 31 & 12.4 & 11 & 2.2 \\
\hline attacks of night suffocation & 85 & 17.0 & 38 & 15.2 & 5 & 2 & 4 & 0.8 \\
\hline wheezing during exercise & 85 & 17.0 & 43 & 17.2 & 27 & 10.8 & 8 & 1.6 \\
\hline $\begin{array}{l}\text { isolated nocturnal cough in the last } \\
12 \text { months }\end{array}$ & 85 & 17.0 & 32 & 12.8 & 5 & 2 & 4 & 0.8 \\
\hline
\end{tabular}


From Table 5 it was found that such an indicator as the presence of AD symptoms in the anamnesis for Shalkar and Irgiz was detected in 37\% (185 children), and in Arys in 48\% (120 children), Ulytau $12.4 \%$ (31 children ), P. Atasu 2.2\% (11 children) cases. The presence of AD symptoms over the past 12 months was found in 22\% (110) and 25\% (62), 11.2\% (28), and $2 \%(10)$, respectively.

To study the function of external respiration (HPF), we used peak flowmetry. 500 children were examined - pos. Shalkar and Irgiz, Aktobe region and 250 children in the village of Arys, South Kazakhstan region for a comprehensive examination of children from 5 to 17 years. Assessment of the severity of obstructive syndrome was carried out as follows: peak flowmetry indicators of $100-80 \%$ of the proper value were regarded as a variant of the norm; $80-70 \%$ - mild obstructive syndrome; 70-60\% - moderate obstructive syndrome; less than $60 \%$ - severe obstructive syndrome.

It was found that the peak expiratory flow rate (PSV) in $89(48.1 \%)$ patients of the villages of Shalkar and Irgiz and $11(9.1 \%)$ of the patients in Arys was $>80 \%$ of the due (normal), in $43(23,2 \%)$ patients Shalkar and Irgiz and 39 (32.5\%) patients of Arys PSV accounted for $<80 \%$ of the due (moderate impairment), in $53(28.6 \%)$ patients of the settlement. Shalkar and Irgiz and 70 (58.3) patients of the Arys settlement, the level of PSV was $<70-60 \%$ of the due (moderate), therefore, the diagnosis of bronchial asthma was made in $205(71 \%)$ children.

The study of the level of total IgE in serum was carried out by the method of an enzyme immunoassay (ELISA). According to the IgE results, it was found that in 32 (17.2) patients of the settlement. Shalkar and Irgiz and $18(15 \%)$ children in the Arys village IgE indicators are within normal limits and in $41(22.1 \%)$ patients in the village of Shalkar, Irgiz and 52 (43.3) children in the city of Arys, the level of IgE was increased, which indicates a hypodiagnosis of $\mathrm{AD}$ in children in these regions; therefore, bronchial asthma was diagnosed in $93(65.4 \%)$ children.

If we compare the results of an epidemiological survey in the Kyzylorda region (Kazalinsky, Aral regions) with indicators in children in the South Kazakhstan region (Arys) and Aktyubinsk region (Shalkar settlement and Irgiz settlement), Karaganda region (Ulytau, p. Atasu), the most common symptoms of bronchial asthma are noted in Arys, South Kazakhstan region $(109,53.1 \%)$, almost 2 times more than in Kyzylorda region.

Thus, according to the results of identified asthma-like symptoms, the diagnosis of AD is confirmed by the results of peak expiratory flow rate (PSV) in $205(71 \%)$ and increased level of immunoglobulin E (IgE) in $93(65.4 \%)$ of the examined children. The survey results allowed to identify children with bronchial asthma who are not registered in the dispensary 205 children.

Identified neurological pathology depending on the regions of residence presented in Table 6.

Table 6. The frequency of identified neurological pathology in children.

\begin{tabular}{|c|c|c|c|c|c|c|c|c|c|}
\hline \multirow[t]{2}{*}{$\begin{array}{l}\text { Identified pathology } \\
\text { ICD-10 }\end{array}$} & \multicolumn{3}{|c|}{$\begin{array}{l}\text { Aktobe region } \\
\text { Irgiz and } \\
\text { Shalkar } \\
\text { (500 kids) }\end{array}$} & \multicolumn{3}{|c|}{$\begin{array}{l}\text { South Kazakhstan } \\
\text { region Arys' } \\
\text { (250 kids) }\end{array}$} & \multicolumn{3}{|c|}{$\begin{array}{l}\text { Karagandy region. } \\
\text { Atasu and Ulytau } \\
\text { (750 kids) }\end{array}$} \\
\hline & $\mathrm{n}$ & $\%$ & $\mathrm{~m}$ & $\mathrm{n}$ & $\%$ & $\mathrm{~m}$ & $\mathrm{n}$ & $\%$ & $\mathrm{~m}$ \\
\hline $\begin{array}{l}\text { Residual organic lesion of the } \\
\text { central nervous } \\
\text { development delay }\end{array}$ & 3 & 0,6 & 0,4 & 10 & 4,0 & $1,2 * * *$ & 4 & 0,5 & 0,3 \\
\hline G80 Cerebral palsy & 3 & 0,6 & 0,4 & 2 & 0,8 & 06 & 3 & 0,4 & 0,2 \\
\hline $\begin{array}{l}\text { G93.4 Encephalopathy, } \\
\text { unspecified } \\
\text { G91.3 Unspecified post-traumatic } \\
\text { hydrocephalus }\end{array}$ & 12 & 2,4 & 0,7 & 6 & 2,4 & 1,0 & 7 & 0,9 & 0,3 \\
\hline
\end{tabular}




\begin{tabular}{|c|c|c|c|c|c|c|c|c|c|}
\hline $\begin{array}{l}\text { R56.8 Other and unspecified } \\
\text { convulsions }\end{array}$ & 7 & 1,4 & 0,5 & 2 & 0,8 & 0,6 & 1 & $0,1 * *$ & 0,1 \\
\hline $\begin{array}{lll}\text { F48.9 } & \text { Unspecified } & \text { neurotic } \\
\text { disorder } & & \\
\end{array}$ & 2 & 0,4 & 0,3 & 2 & 0,8 & 0,6 & 7 & 0,9 & 0,3 \\
\hline $\begin{array}{l}\text { F80 Specific disorders of speech } \\
\text { and language }\end{array}$ & 6 & 1,2 & 0,5 & 9 & 3,6 & 1,2 & 12 & 1,6 & 0,5 \\
\hline Hypothalamic syndrome & 5 & 1,0 & 0,5 & 8 & 3,2 & 1,1 & 18 & 2,4 & 0,6 \\
\hline Consequences of stroke & - & - & 0,2 & - & - & 0,4 & 1 & 0,1 & 0,1 \\
\hline Astheno-neurotic syndrome & 22 & 4,4 & 0,9 & 15 & 6,0 & $1,5 * * *$ & 9 & $1,2 * *$ & 0,4 \\
\hline $\begin{array}{l}\text { Residual-organic damage to the } \\
\text { central nervous system. } \\
\text { Hypertension-hydrocephalic } \\
\text { syndrome }\end{array}$ & 78 & 15,6 & $1,6^{*}$ & 3 & 1,2 & $0,7 * * *$ & 23 & $9,2 * *$ & 1,1 \\
\hline $\begin{array}{l}\text { P14.0 Erba paralysis due to birth } \\
\text { injury }\end{array}$ & 1 & 0,2 & 0,2 & 1 & 0,4 & 0,4 & - & 0 & 01 \\
\hline Q90 Down Syndrome & - & 0 & 0,2 & 1 & 0,4 & 0,4 & - & 0 & 0,1 \\
\hline Q03 Congenital hydrocephalus & 3 & 0,6 & 0,4 & 1 & 0,4 & 0,4 & - & 0 & 0,1 \\
\hline Arachnoid cyst & - & 0 & 0,2 & 1 & 0,4 & 0,4 & - & 0 & 0,1 \\
\hline Neurodegenerative disease & 1 & 0,2 & 0,2 & - & 0 & 0,4 & - & 0 & 0,1 \\
\hline Healthy children & 357 & 71,4 & 2,0 & 189 & 75,6 & $2,7 * * *$ & 665 & 88,7 ** & 1,2 \\
\hline
\end{tabular}

From the presented table 6 it can be seen that neurological pathology among children is represented by a significant number of cases in all studied areas: $28.6 \%$ - in the Aktobe region; $24.6 \%$ - in the South Kazakhstan region and $12.7 \%$ in the Karaganda region. In the latter case, a significant difference was determined in the level of frequency of detection of neurological pathology. It should be noted that among the detected pathology, one cannot distinguish any prevailing nosology, with the exception of the astheno-neurotic syndrome and hypertension syndrome, which were detected in a significant part of cases in all regions $-15.6 \%-9.2 \%$. As for the differences by region, it should be pointed out that no special differences were determined by region, especially for the Aktobe region and the South Kazakhstan region.

Psychological testing aimed at a separate assessment of anxiety as a personality trait, as well as anxiety that developed as a result of the impact of society, ie, situational anxiety was carried out according to the Spielberg-Khinin method [19]. Regarding the nature of psychological disorders, here there were significant differences in the frequency of cases of reactive anxiety: the lowest in the South Kazakhstan region, a similar picture was observed with respect to personal anxiety (Table 7).

Table 7. The frequency of detected reactive and personal anxiety in children.

\begin{tabular}{|l|c|c|c|c|c|c|c|c|c|}
\hline \multirow{2}{*}{$\begin{array}{c}\text { Level of } \\
\text { anxiety }\end{array}$} & \multicolumn{3}{c|}{$\begin{array}{c}\text { Aktobe region } \\
\text { Irgiz and Shalkar } \\
\text { (500 kids) }\end{array}$} & \multicolumn{2}{c|}{$\begin{array}{c}\text { South Kazakhstan region } \\
\text { Arys' } \\
(250 \mathrm{kids})\end{array}$} & \multicolumn{3}{c|}{$\begin{array}{c}\text { Karagandy region. } \\
\text { Atasu and Ulytau } \\
\text { (750 kids) }\end{array}$} \\
\cline { 2 - 11 } & $\mathrm{n}$ & $\%$ & $\mathrm{~m}$ & $\mathrm{n}$ & $\%$ & $\mathrm{~m}$ & $\mathrm{n}$ & $\%$ & $\mathrm{~m}$ \\
\hline \multicolumn{8}{|c|}{ Reactive anxiety } \\
\hline Low anxiety & 105 & 21,0 & $1,8^{*}$ & 150 & $60,0^{* * *}$ & 3,1 & 181 & 24,1 & 1,6 \\
\hline $\begin{array}{l}\text { Moderate } \\
\text { anxiety }\end{array}$ & 115 & 29,0 & $2,0^{*}$ & 15 & $6,0^{* * *}$ & 1,5 & 207 & 27,6 & 1,6 \\
\hline High anxiety & 250 & 50,0 & $2,2^{* *}$ & 85 & 4,0 & 3,0 & 362 & 48,3 & 1,8 \\
\hline \multicolumn{8}{|c|}{ Personal anxiety } \\
\hline Low anxiety & 105 & 21,0 & $1,8^{*}$ & 125 & $50,0^{* * *}$ & 3,2 & 221 & 29,5 & 1,7 \\
\hline
\end{tabular}




\begin{tabular}{|l|c|c|c|c|c|c|c|c|c|}
\hline $\begin{array}{l}\text { Moderate } \\
\text { anxiety }\end{array}$ & 110 & 22,0 & $1,9^{*}$ & 85 & 34,0 & 3,0 & 216 & $28,8^{* *}$ & 1,7 \\
\hline High anxiety & 285 & 57,0 & $2,2 *$ & 40 & $16,0 * * *$ & 2,3 & 313 & $41,7 * *$ & 1,8 \\
\hline
\end{tabular}

The highest level of anxiety (57.0\%) was recorded in children of the Aktobe region, and the lowest level of anxiety was determined in children of the Karaganda region $-40.0 \%$. The revealed psychological characteristics of children in the Aral Sea region are manifested by emotional instability, increased excitability. It should be noted the high frequency of anxiety, both reactive and personal, in the Aktobe and Karaganda regions. The number of children with general surgical and nephro-urological pathology was $222(14.8 \%)$ children. Early and timely diagnosis makes it possible to determine the presence of both congenital and acquired surgical pathologies, which is fundamentally important in the choice of medical tactics, including surgical treatment, which helps to restore and improve the anatomical and physiological activity of the body. Neurogenic bladder dysfunction prevails from all groups of diseases of the urinary system in children and is found in almost equal proportions in the studied regions. The remaining diseases were detected in small quantities, as in other regions of the Republic of Kazakhstan. The distribution of nosologies is presented in Table 8.

Table 8. The frequency of identified surgical and urological pathologies in children.

\begin{tabular}{|c|c|c|c|c|c|c|c|c|c|c|}
\hline \multirow{2}{*}{ Identified pathologies, ICD } & \multicolumn{2}{|c|}{ Irgiz } & \multicolumn{2}{|c|}{ Shalkar } & \multicolumn{2}{|c|}{ Arys' } & \multicolumn{2}{|c|}{ Ulytau } & \multicolumn{2}{|c|}{ Atasu } \\
\hline & $\mathrm{n}$ & $\%$ & $\mathrm{n}$ & $\%$ & $\mathrm{n}$ & $\%$ & $\mathrm{n}$ & $\%$ & $\mathrm{n}$ & $\%$ \\
\hline $\begin{array}{l}\text { Congenital malformations of the } \\
\text { colon. } \\
\text { Chronic constipation Q42 Q43 } \\
\text { K59.0 }\end{array}$ & 4 & 1,8 & 3 & 1,3 & 2 & 0,9 & 3 & 1,3 & - & - \\
\hline $\begin{array}{l}\text { Benign cystic formations of the } \\
\text { liver and kidneys K76 Q61 }\end{array}$ & 1 & 0,4 & 3 & 1,3 & 2 & 0,9 & 3 & 1,3 & 1 & 0,4 \\
\hline Polydactyly Q69 & 4 & 1,8 & 2 & 0,9 & 3 & 1,3 & - & - & - & - \\
\hline $\begin{array}{l}\text { Chest deformity } \\
\text { Q67.8 }\end{array}$ & 5 & 2,2 & 7 & 3,1 & 10 & 4,5 & 6 & 2,7 & 5 & 2,2 \\
\hline Flat feet Q66.5 & 2 & 0,9 & 2 & 0,9 & 3 & 1,3 & 2 & 0,9 & 2 & 0,9 \\
\hline $\begin{array}{l}\text { Spinal curvature } \\
\text { kyphosis, lordosis) M41 M40 }\end{array}$ & 7 & 3,1 & 9 & 4,0 & 12 & 5,4 & 7 & 3,1 & 9 & 4,0 \\
\hline Congenital hip dislocation Q65.0 & 1 & 0,4 & 1 & 0,4 & 1 & 0,4 & 2 & 0,9 & - & - \\
\hline Inguinal scrotal hernia K40.9 & 2 & 0,9 & 1 & 0,4 & 2 & 0,9 & 1 & 0,4 & 1 & 0,4 \\
\hline $\begin{array}{l}\text { Neurogenic bladder dysfunction. } \\
\text { Enuresis N31.8 }\end{array}$ & 10 & 4,5 & 8 & 3,6 & 11 & 4,9 & 2 & 0,9 & 4 & 1,8 \\
\hline $\begin{array}{l}\text { Undescended testicle unilateral } \\
\text { Q53.1 }\end{array}$ & 1 & 0,4 & 1 & 0,4 & 2 & 0,9 & - & - & 1 & 0,4 \\
\hline Varicocele I86.1 & 1 & 0,4 & - & - & 2 & 0,9 & 1 & 0,4 & 1 & 0,4 \\
\hline Osteochondropathy M93.1 & 1 & 0,4 & - & - & - & - & - & - & - & - \\
\hline $\begin{array}{l}\text { Dropsy of testicular membranes } \\
\text { N43 }\end{array}$ & - & - & - & - & - & - & 1 & 0,4 & - & - \\
\hline Congenital hydronephrosis Q62.0 & - & - & 1 & 0,4 & 1 & 0,4 & - & - & 1 & 0,4 \\
\hline Chronic cystitis N30 & 1 & 0,4 & 1 & 0,4 & - & - & - & - & 1 & 0,4 \\
\hline Hypospadias Q54.1 & - & - & - & - & 1 & 0,4 & - & - & - & - \\
\hline Chronic pyelonephritis N11.1 & 2 & 0,9 & 3 & 1,3 & 2 & 0,9 & - & - & 1 & 0,4 \\
\hline Bladder diverticulum Q64 .6 & - & - & - & - & - & - & - & - & 1 & 0,4 \\
\hline
\end{tabular}


According to the survey, $74(33.4 \%)$ children were diagnosed with a surgical diagnosis for the first time, and 148 children $(66.6 \%)$ were registered at the dispensary. Thus, the results of the examination revealed children with surgical pathology who are not registered in the dispensary, which in the future is very important for the treatment and prevention of complications.

A sociological survey showed that at the time of birth, pregnancy was complicated by diseases of the urinary system in $26.9 \%$ of cases, iron deficiency anemia occurred in almost a third of women, chronic conditions of the cardiovascular system in $6.9 \%$, respiratory diseases and infectious -parasitic diseases of more than $9.5 \%$. In $8.2 \%$ of cases, there were reproductive system disorders and in $40 \%$ of cases, complications during pregnancy.

Almost half of the respondents $(48.3 \%)$ rated their living conditions as unsatisfactory, $36.6 \%$ said they were satisfactory, and only $15.1 \%$ of families lived with good living conditions. The low educational level defined in fathers was $40.8 \%$, in mothers $-38.6 \%$. The social composition was dominated by workers $(40.7 \%)$. Large families accounted for $33 \%$ of respondents and in $11.0 \%$, children were from single-parent families. More than half of the families $(65.3 \%)$ had a low material status, which was confirmed by the lack of a permanent job for every second mother and every fourth father. More than $35.1 \%$ of families could not provide a balanced diet for children; they were mainly on flour products with a lack of the required amount of protein products and vitamins. In our studies, parents with bad habits accounted for $35.8 \%$ of cases. The condition of a child's CVS also depends on the psychological climate in the family, as $62.0 \%$ of the families surveyed have good, friendly relations, $26.0 \%$ report conflicts in the family once a week, and $12.0 \%$ have a tense family situation. daily.

Thus, the studies indicate a low level of children's health in environmentally disadvantaged regions, which may be one of the significant factors contributing to the formation of various forms of chronic pathology.

\section{Conclusion}

1. In the examined children, in the first place is the II group of health $(50.0 \%)$, then III $(28.7 \%)$. This distribution indicates the predominance of functional abnormalities among children in the Aral Sea region, and among 11-15 year old children - chronic diseases. Healthy children accounted for only $9.2 \%$.

2. In the structure of functional abnormalities in children of the Aral Sea region, in $55.2 \%$ (276) cases there was a vegetative dysfunction, which was more often detected in children of pre- and puberty age (78.9\%) and mainly in girls (80.8\%). In children in the Aral Sea region (Shalkar, Irgiz, Arys), vegetative dysfunction was observed almost twice as often $(>46.3 \%)$ than in children living in the Karaganda region (Ulytau - 29.2\% and Atasu $24.6 \%$ ) More than one third of the children in the Aral Sea region have a distinct tendency to hypotension.

3. Under the ISSAC program, 205 children with asthma are not registered in the dispensary.

4. The structure of the digestive tract pathology was dominated by lesions of the hepatobiliary system $(62.0 \%)$ and functional dyspepsia (52.2\%). The frequency of pancreatic pathology was greatest among children in the city of Arys - 49.9\%, among children in the Irgiz and Shalkarsky districts, it was observed on average in 44.2\%, among children in the villages of Atasu and Ulytau of the Karaganda region on average in $30 \%$ of cases.

5. The frequency of IDA in terms of hemoglobin in children was not high. However, in the village of Irgiz IDA was more common - 19.6\%. In the surveyed regions, IDA prevails among older adolescents. From 15-17 years old, making up 40.5\% (s. Atasu); $40 \% \mathrm{~s}$ Ulytau, $41.6 \%$ of s. Arys, $26.5 \%$ of the village of Kyrgyzstan, $58.3 \%$ of the children of 
the village of Shalkar. Although, in industrialized countries, IDA despite a significant reduction in prevalence remains a common cause of anemia among young children. IDA mainly in the examined children was I severity: $66.6 \% ; 73.3 \% ; 87.5 \% ; 91.8 \% ; 75 \%$ respectively.

6. Neurological pathology among children is presented in all studied areas: $28.6 \%$ - in the Aktobe region; $24.6 \%$ - in the South Kazakhstan region and $12.7 \%$ in the Karaganda region. The highest level of anxiety (57.0\%) was recorded in children of the Aktobe region, and the lowest level of anxiety was determined in children of the Karaganda region $-40.0 \%$. The revealed psychological characteristics of children in the Aral Sea region are manifested by emotional instability, increased excitability.

7. The number of children with general surgical pathology was $222(14.8 \%)$ children. Among the identified nosologies, a very significant group was composed of pathologies of the musculoskeletal system - 92 children (41.4\%). In 74 children, the diagnosis with a general surgical pathology was first established, which amounted to $33.4 \%$. Whereas, before the examination, there were 148 children $(66.6 \%)$ on the DU.

8. As a result of questionnaires on the medical and social status of families, $48.6 \%$ rated their living conditions as unsatisfactory, $36.6 \%$ rated their living conditions as satisfactory, and only $15.1 \%$ of families live in good living conditions. More than half $(58.1 \%)$ of the respondents are not completely satisfied with their material security, while the rest are only partially satisfied. The most disadvantaged regions in terms of their socio-economic situation were the areas of Arys (South Kazakhstan region), Irgiz (Aktobe region) and Ulytau (Karaganda region), and the most prosperous - Shalkar (Aktobe region). ) and Atasu settlement (Karaganda region).

\section{References}

1. Z. Kh. Mazhitova, Environmentally dependent diseases in children (clinic, pathomorphogenesis, diagnosis, treatment, rehabilitation), 400 (Format, Almaty, 2007)

2. Ministry of Environment and Water Resources of the Republic of Kazakhstan, The newsletter on the state of the environment in the Republic of Kazakhstan for 2011

3. F. I. Ingel, Ecological genetics, 3, 17-19 (2005)

4. A. Ingel, Sh. Khusainova, L. Erdinger et al., Pediatrics and pediatric surgery, 4, 37-42 (2012)

5. M. A. Shkolnikova, G. G. Osokina, I. V. Abdulatipova, Cardiology, 43 (8), 4-8 (2003)

6. A. M. Wayne, Vegetative disorders: clinic, treatment, diagnosis, 749 (Medical News Agency, 2003)

7. Statistical Digest, The health of the population of the Republic of Kazakhstan and the activities of healthcare, 39-41 (Astana, 2019)

8. World Health Organization, Global Database on Iron Deficiency and Anaemia, Micronutrient Deficiency Information System (Geneva, 2005)

9. K. S. Ormantaev, Sh. N. Khusainova, Pediatrics and pediatric surgery in Kazakhstan, 3, 35-37 (2012)

10. A. D. Dmitrieva, D. A. Dmitriev, I. I. Romanova et al., Hygiene and sanitation, 2, 41$43(2003)$

11. E. I. Kukhtina, Quality of life for children with disabilities with cerebral palsy, 23 (Ufa, 2006)

12. V. I. Strukov, News of higher educational institutions of the Volga regions. Medical science, 1, 121-135 (2009)

13. M. V. Krasilnikova, Iron deficiency in adolescents: frequency characteristics, structure and secondary prevention (Moscow, 2006) 
14. N. A. Korovina, I. N. Zakharova, L. P. Gavryushova, T. M. Tvorogova, E. B. Mumladze, E. V. Skorobogatova, Vegetative dystonia in children and adolescents, 60 (Medpraktika, Moscow, 2009)

15. L. K. Antonova, Social hygiene issues, 6, 7-9 (2003)

16. R. B. Issayeva, Features of combined chronic pathology in children in the environmentally disadvantaged region of the Aral Sea region (Author, Moscow, 2007)

17. M. M. Bayzhanova, Pediatrics pediatric surgery of Kazakhstan, 2, 7-9 (2011)

18. Sh. T. Nauryzalieva, Factor characteristic and clinical and functional aspects of bronchial obstructive conditions in children of Almaty, 95 (Almaty, 2010)

19. N. D. Bobrishcheva-Pushkina, Determining the level of mental health of children and adolescents. Educational-methodical manual for students, 31 (MMA named after IM Sechenov, publishing house "Russian Doctor", 2002) 